\title{
A STUDY OF HEDGE FUND REDEMPTION AND ITS BANKRUPTCY IMPLICATIONS
}

\author{
$\mathrm{Ye} \mathrm{Li}^{*}$
}

This research paper will focus on the legal realities of redemption of funds, the fraudulent conveyances and possibly bankruptcy implication for investors in hedge funds. This paper will also attempt to clarify the current state of these legal issues, and what will be the aggregate result of developed law in the area and hence its implications for hedge fund investors.

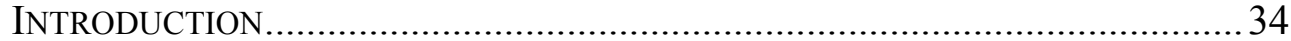

I. THE LEGAL STRUCTURE OF HEDGE FundS ………....................................36

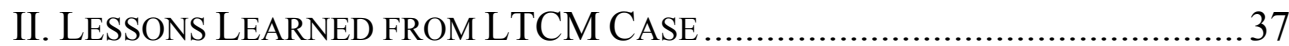

III. HEDGE FUND REDEMPTION APPROACH AND EXIT STRATEGY ...................4 41

IV. REDEMPTION RELATED ISSUES AND FRAUDULENT CONVEYANCE

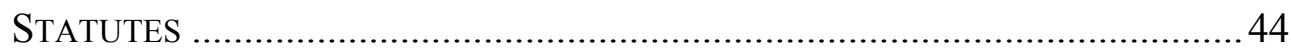

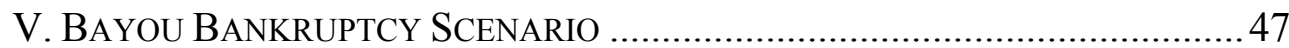

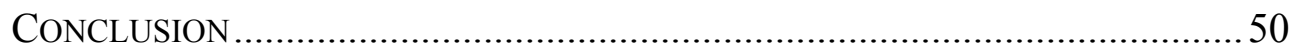

\section{INTRODUCTION}

Hedge funds have become a hot topic of great media scrutiny, buoyed by the veil of secrecy that cloaks much of their actions. The primary concern amongst investors and speculators centered on being able to get their money in to hedge funds, lucrative high growth potential funds that have used leveraged maneuvers in recent years to yield tremendous returns. ${ }^{1}$ This activity was made possible largely by cheap credit, which seemed for a period to be in endless supply. Highly secretive fund managers were able to use these market conditions to their advantage, leveraging their way into status as the current golden boys of Wall Street. ${ }^{2}$ However, with the rapid change of market sentiments, for the first time in years, the question on the minds of speculators and institutional investors alike is not how to get

\footnotetext{
* Ye Li, Lecturer in Law, Jiangxi University of Economics and Finance, China. Research fields: civil and commercial law.

${ }^{1}$ Jenny Anderson, Atop Hedge Funds, Richest of the Rich Get Even More So, N.Y. TIMES, May 26, 2006, at C2.

${ }^{2}$ Boyson Nicole M., Stahel Christof W., \& Stulz René M., Is There Hedge Fund Contagion? (March 13, 2007). "Wall Street' is used in the colloquial sense, as it should be noted that, the vast majority of hedge fund managers conduct their business via computer from plush locales such as Greenwich, Connecticut."
} 
money in to the hottest hedge funds, but how to get it out. ${ }^{3}$

Because of their extreme leveraged positions, many hedge funds are susceptible to downturns, and even total collapse. This does not mean that, hedge funds are going away; it simply means that some will fail. Getting money out of these funds is of special legal consequence now, as the climate is shifting toward such a desire that has not been examined in much detail. This is compounded in the case of insolvency, which brings up questions related to the fraudulent conveyance statue, and at what point a hedge fund is considered insolvent under the fraudulent conveyance statute. ${ }^{4}$ The market players who have their money in hedge funds range from the rogue speculator, to the mighty institutional investors such as large pension funds and university endowments. A year ago, the hedge fund machine seemed to be an unstoppable force, but now, the prospects of large Wall Street investment banks may hinge on the viability of their flagship hedge funds. ${ }^{5}$

With buyouts now being renegotiated and debt lingering in the air on hanging deals, it is easy to decry the plight of the hedge fund. ${ }^{6}$ It is impossible to say if the credit squeeze will continue, or if so, whether fund mangers will be able to devise new methods for turning quick return. Regardless of the path the market will take, it is now apparent that, hedge funds are not the invulnerable fortresses in which the rich can generate massive returns with relatively low risk.

With risk spread throughout the market by quants and funds of funds, exacerbated by the copycat nature of the hedge fund business, many legal implications come to the foreground in terms of getting money out of these funds, and exposure to risk in cases of fund bankruptcy. Hedge funds will likely to continue to grow in power. Some funds will fail, but such is the nature of capital markets. This does not mean that, hedge funds will all be in trouble; on the contrary, hedge funds will continue to play an increasingly important part in the global economy.

The high number of funds, coupled with the fact that, funds deal with extreme leverage, means that some funds will fail. The current credit crisis will not cripple the hedge fund by any means, but what it does is show that, funds acting in extreme leverage can be vulnerable to market conditions. For the sake of investors, who will continue to pour money into these funds, it is essential that, we examine the prospects of getting money out of these funds,

\footnotetext{
${ }^{3}$ Jeff D. Opdyke, \& Eleanor Laise, Investors Mull How to Get Out of Hedge Funds: Market Turmoil Highlights Notoriously Tricky Rules For Redeeming Shares, Wall StreEt Journal, Aug. 15, 2007, at B1.

${ }^{4}$ Id.

${ }^{5} I d$.

${ }^{6} I d$.
} 
and what happens in insolvency cases.

People now want to know how they can get out of these funds, whether they are still solvent or have become insolvent. Lawyers for wealthy investors and speculators will have to be prepared to address such questions from clients, who are understandably worried and want to avoid the proverbial run on the hedge fund bank. ${ }^{7}$ This paper will not address issues of hedge fund regulation, nor make arguments for registration and transparency standards to be implemented in much the same way mutual funds are regulated. ${ }^{8}$ Instead, this paper will examine the legal realities of redemption of funds, fraudulent conveyances and bankruptcy implication for investors in hedge funds.

\section{The Legal Structure of Hedge FundS}

Unlike mutual funds, which are highly regulated, hedge funds are not required to redeem investors' assets within seven days from the date on which it receives a notice for redemption from an investor, and may take illiquid positions without limitation and may engage in leveraged transactions with greater freedom. ${ }^{9}$ The legal structure of a hedge fund largely depends upon who its investors will be, though all investors in funds must be financial qualifications that certify them as having sufficient assets to bear the risk of investing in a hedge fund. ${ }^{10}$

For the purpose of managing the assets of persons residing in the United States, a hedge fund is ordinarily organized as a limited partnership. ${ }^{11}$ By purchasing an interest in the partnership, an investor becomes a limited partner of the partnership. ${ }^{12}$ Thus, the terms, including redemption of funds, will be contained in the partnership agreement. ${ }^{13}$ Depending on the laws of the state in which the general partner will maintain its office, the hedge fund manager will organize the general partner as a limited liability company, corporation or limited partnership. ${ }^{14} \mathrm{In}$ certain cases, however, the manager will form two entities, one entity to serve as the general partner and the other entity to serve as a management

\footnotetext{
${ }^{7}$ See Supra note 3.

${ }^{8}$ For such arguments, see: Douglas L. Hammer et al, U.S. Regulation OF Hedge Funds 1 (2005).

${ }^{9}$ Id.

${ }^{10}$ Implications of the Growth of Hedge Funds, SEC STAFF REPORT 78. Available at http://www.sec.gov/news/studies/hedgefunds0903.pdf.

${ }^{11} I d$.

${ }^{12} I d$.

${ }^{13} I d$.

${ }^{14}$ Id.
} 
company. ${ }^{15}$

For the purpose of managing the assets of persons residing outside of the United States, an offshore fund is ordinarily structured as a corporation and organized in a tax haven jurisdiction. ${ }^{16}$ The jurisdiction in which the fund is organized often depends on the countries in which investors reside and the type of entity the sponsor desires to form. ${ }^{17}$ Also, certain jurisdictions, such as the Cayman Islands, have a well-developed regulatory system for organizing and maintaining investment funds but are more expensive than other jurisdictions, such as the British Virgin Islands, which do not have as extensive a regulatory scheme. ${ }^{18}$

Often, the manager of an offshore fund forms a corporate entity to provide advisory services to the fund. ${ }^{19}$ This entity serves as the investment manager of the fund. ${ }^{20}$ If the hedge fund manager already manages the assets of a domestic partnership through a single corporate entity, the general partner of the partnership may also serve as the investment manager of the offshore fund. ${ }^{21}$ If the sponsor is managing the assets of a partnership through two corporate entities, the entity serving as the management company of the domestic partnership will ordinarily serve as the investment manager to the fund. ${ }^{22}$

\section{LESSONS LEARNED FROM LTCM CASE}

In order to understand the current issue with hedge fund insolvency and redemption issues, it is essential to look at the first manifestations of similar events. The recent collapse of two large Bear Stearns funds is not the first time a high profile hedge fund has defaulted. The infamous demise of Long Term Capital Management (LTCM) in 1998 set the precedent for actions in hedge fund insolvency, and serves as a framework for understanding the proceedings that will ensue in future hedge fund meltdowns. ${ }^{23}$ The LTCM episode raises some issues involving the U.S. Bankruptcy Code. ${ }^{24}$ The first

\footnotetext{
${ }_{16}^{15}$ Douglas L. Hammer et al, U.S. Regulation OF Hedge Funds 1 (2005).

${ }^{16} \mathrm{Id}$.

${ }^{17} \mathrm{Id}$.

${ }^{18}$ Alistair MacDonald, A Hedge Haven Makes Its Rules Even Lighter, WaLl Street Journal, Sep. 29, 2007, at B1.

${ }^{19} \mathrm{Id}$.

${ }^{20} \mathrm{Id}$.

${ }^{21} \mathrm{Id}$.

${ }^{22}$ Supra note 10.

${ }^{23}$ Statement on Long-Term Capital Management and the Report of the President's Working Group on Financial Markets, The Financial Economists Roundtable, Oct. 6, 1999. See Franklin R. Edwards, Insolvency Law and Financial Stability in OTC Derivatives Markets, WORKING PAPER, March, 2003. ${ }^{24} I d$.
} 
involves clarifying the ability of certain counterparties to exercise their rights with respect to closeout, netting, and liquidation of underlying collateral in the event of the filing of a bankruptcy petition without regard to the Bankruptcy Code's automatic stay. ${ }^{25}$

These provisions, which the President's Working Group on Financial Markets urged Congress last year to expand and improve, are generally recognized to be important to market stability. ${ }^{26}$ They serve to reduce the likelihood that, the procedure for resolving a single insolvency will trigger other insolvencies due to the creditors' inability to control their market risk. ${ }^{27}$ In other words, this protects the market from the systemic problem of "domino failures." 28

Nevertheless, in certain circumstances, a simultaneous rush by the counterparties of a defaulting market participant to replace their contracts could put pressure on market prices. ${ }^{29}$ To the extent that the default was due to fluctuations in market prices in these contracts, this pressure might tend to exacerbate those fluctuations, at least in the near term. ${ }^{30}$ This problem could be significant where the defaulting debtor had large positions relative to the size of the market. The possibility of a debtor defaulting during volatile markets where the debtor had large positions relative to the size of certain markets, was the specter created by the potential default of the LTCM Fund. $^{31}$

In the highly volatile markets of September, 1998, the failure of the LTCM Fund would have left a number of creditors with open market positions subject to extreme volatility. ${ }^{32}$ Termination of those contracts would have required counterparties to replace contracts that, they held with the LTCM Fund in the relatively near term. ${ }^{33}$ However, had termination not been available to the LTCM Fund's counterparties in the bankruptcy process, the uncertainty as to whether these contracts would be performed would have created great uncertainty and disruptions in these same markets, coupled with substantial uncontrollable market risk to the counterparties. ${ }^{34}$ The inability to exercise closeout netting rights could well have resulted in

\footnotetext{
${ }^{25} I d$.

${ }^{26} I d$.

${ }^{27} I d$.

${ }^{28} I d$.

${ }^{29} I d$.

${ }^{30} \mathrm{Id}$.

${ }^{31}$ Coy Peter, \& Wooley Suzanne, Failed Wizards of Wall Street, Business WeEK, Sep. 21, 1998.

${ }^{32} I d$.

${ }^{33}$ Franklin R. Edwards, Hedge Funds and the Collapse of Long-Term Capital Management, 13(2)

The Journal of EConomic Perspectives 189-210 (Spring 1999).

${ }^{34} I d$.
} 
an even worse market situation if the LTCM Fund had filed for bankruptcy than the exercise of such rights in this situation. ${ }^{35}$

Why was Federal Reserve intervention necessary? The intervention of the Federal Reserve to head-off the insolvency of LTCM raises a serious systemic concern that still exists and is not widely understood. Further, this systemic concern is not specific to hedge funds but arises out of the pervasive use of derivatives by financial market participants. The fundamental reason that the Federal Reserve intervened in the LTCM case is that, bankruptcy law in the United States (and in most other countries) does not treat derivatives counterparties as it does all other creditors. Specifically, current U.S. bankruptcy law exempts derivatives counterparties from the normal operation of the Bankruptcy Code, and in particular from the automatic stay provisions of the Code. ${ }^{36}$

As a consequence, had LTCM been unable to meet its obligations and filed for protection under Chapter 11, its derivatives counterparties could still have, and certainly would have, immediately terminated their contracts with LTCM, resulting in the “... abrupt and disorderly closeout of LTCM's positions which would [have] pose[d] unacceptable risks to the American economy." ${ }^{, 37}$ Only the intervention of the Federal Reserve in arranging a creditor-bailout enabled LTCM to avoid a bankruptcy filing, which would have triggered the immediate liquidation of its positions. ${ }^{38}$

In principle, the same result could have been achieved without the intervention of the Federal Reserve, had the Bankruptcy Code not exempted LTCM's derivatives counterparties from the automatic stay provision of the Code. ${ }^{39}$ In that case, a bankruptcy filing by LTCM would have "stayed" LTCM's derivatives counterparties, as well as its other creditors, and would have resulted in a court-supervised creditor-workout of LTCM's positions. ${ }^{40}$ As subsequent events have shown, it was clearly in the joint interests of LTCM's creditors, to avoid a "fire sale" of LTCM's positions and to facilitate a creditor "work-out" by putting in more capital and reorganizing the ownership structure of LTCM. ${ }^{41}$ Many economists argue that, had the

\footnotetext{
${ }^{35} \mathrm{Id}$.

${ }^{36} \mathrm{Id}$.

${ }^{37}$ See Coy, supra note 19.

${ }^{38}$ See Edwards, supra note 21.

${ }^{39} \mathrm{Id}$.

${ }^{40}$ Statement on Long-Term Capital Management and the Report of the President's Working Group on Financial Markets, The FinanCial EconOMists RoundTABLE, Oct. 6, 1999. See Franklin R. Edwards, Insolvency Law and Financial Stability in OTC Derivatives Markets, WORKING PAPER, March, 2003. ${ }^{41} I d$.
} 
bankruptcy code allowed this, there would have been no need for the Federal Reserve to intervene. ${ }^{42}$

Ironically, the potential destabilizing role that bankruptcy law played in the LTCM crisis was the result of series of changes in the Bankruptcy Code made by the U.S. Congress, in order to reduce the likelihood of systemic instability in off-exchange derivatives markets. ${ }^{43}$ The rationale for exempting "derivatives securities" contracts from the automatic stay provisions of the Bankruptcy Code is that, this exemption is necessary to maintain the liquidity and stability of derivatives markets to prevent the "insolvency of one commodity or security firm spreading to other firms and possibly threatening the collapse of the affected market." ${ }^{44}$ Congress believed that: "The prompt liquidation of an insolvent's position is generally desirable to minimize the potentially massive losses and chain reaction of insolvencies that could occur if the market were to move sharply in the wrong direction." 45

In interpreting the scope of the exceptions to the Bankruptcy Code, the bankruptcy appellate panel for the Ninth Circuit cited the comments of Senator Dole, during the Senate discussion on the amendment to Section 362 of the Bankruptcy Code: "It is essential that, stockbrokers and securities clearing agencies be protected from the issuance of a court or administrative agency order which would stay the prompt liquidation of an insolvent's positions, because market fluctuations in the securities markets create an inordinate risk that, the insolvency of one party could trigger a chain reaction of insolvencies of the others who carry accounts for that party and undermine the integrity of those markets." 46

In retrospect, it seems clear that, had LTCM's derivatives counterparties not been exempted from the automatic stay provisions of the Bankruptcy Code, there would not have been either an "... abrupt and disorderly close-out of LTCM's positions ...” or an “... unwinding [of] LTCM's portfolio in a forced liquidation ...," and there would have been no need for the Federal Reserve to intervene to prevent a “... seizing up of markets ... that could have potentially impaired the economies of many nations, including our own."

The major systemic risk issue raised by the near-collapse of LTCM is whether recent revisions to the bankruptcy law in the United States, and

\footnotetext{
${ }^{42} I d$.

${ }^{43} \mathrm{Id}$.

${ }^{44} I d$.

${ }^{45} \mathrm{Id}$.

${ }^{46}$ See id.

${ }^{47} \mathrm{Id}$.
} 
other countries have created another source of financial instability in financial markets by enabling a counterparty run on the positions of a financially-stressed counterparty. ${ }^{48}$ As LTCM illustrated, a "counterparty run" has the potential to result in a systemic liquidity shortage, with uncertain and potentially damaging economic effects. ${ }^{49}$ It is notable that, some recent academic papers have argued that, a "fire sale" of financial assets can cause or exacerbate liquidity shortages, resulting in systemic illiquidity with the potential to cause runs and threats to overall capital markets. $^{50}$

\section{HEDGE Fund REDEMPTION APPROACH AND EXIT STRATEGY}

If getting out of funds were simple, lawyers would not need to be intricately involved, nor would heavily invested individuals be so worried over the prospects of getting their money out. Hedge funds, however, have notoriously tricky rules regarding such exits, even though it would seem to be a simple matter of a clause in the partnership agreement. ${ }^{51}$ Exiting from a hedge fund can be far more complex than selling a stock or a mutual fund. ${ }^{52}$ Redemption policies vary widely. Most funds will redeem your money only at the end of a calendar month, or the end of a quarter. And you generally must provide written notice in advance that you intend to redeem money. The notice period is often 30 days to 60 days, but some funds require as many as 90 days or more. ${ }^{53}$ Rules for redeeming money from a hedge fund are generally laid out in the limited-partnership agreement. ${ }^{54}$

The long notice period means that, investors might not see their money for weeks, or even months, in which time markets might shift dramatically. ${ }^{55}$ Also, fleeing funds now won't help avoid losses already booked. And troubled funds may freeze the ability of investors to redeem their money to keep from having to dump assets at falling prices, as Bear Stearns did recently with its Bear Stearns High-Grade Structured Credit Strategies Enhanced Leverage Fund.

For investors trying to gauge their own situation, the key challenge is

\footnotetext{
${ }^{48} I d$.

${ }^{49} \mathrm{Id}$.

${ }^{50}$ See id.

${ }^{51}$ Jeff D. Opdyke, \& Eleanor Laise, Investors Mull How to Get Out of Hedge Funds: Market Turmoil Highlights Notoriously Tricky Rules For Redeeming Shares, Wall StreEt Journal, Aug. 15, 2007, at B1.

${ }_{52}^{52} \mathrm{Id}$.

${ }^{53} \mathrm{Id}$.

${ }^{54} \mathrm{Id}$.

${ }^{55} \mathrm{Id}$.
} 
knowing what your hedge fund owns. ${ }^{56}$ Hedge funds typically have just a limited number of investors, often no more than a few hundred, so your chances of talking to someone that matters are pretty good. ${ }^{57}$ This is particularly true if you have a large amount of money invested, especially the case with large institutional investors who are sure to get a receptive ear from fund management. If a fund is being inundated with calls, it might set up a conference call aimed at explaining the current situation to all investors at once. ${ }^{58}$ Investors can also review quarterly " $13 \mathrm{~F}$ " filings, in which hedgefund managers with more than $\$ 100$ million in certain public securities must disclose those holdings to the Securities and Exchange Commission. ${ }^{59}$ But these filings may not be useful to look inside some of the quant funds that are now stumbling, because such funds can make thousands of trades a day. ${ }^{60}$

If investors think that, there is a problem brewing or already present with their fund, they should make their redemption quickly to avoid a traffic jam. ${ }^{61}$ Overall, the industry comprises roughly 6,000 to 8,000 U.S. hedge funds that manage about $\$ 1.5$ trillion in assets. ${ }^{62}$ Still, investor nervousness goes beyond the hardest-hit funds that invest in subprime mortgages and make use of quants. The anxious investor attempting to reach those in fund management kind of call has been common in recent months, where funds from smaller, rogue capital groups have posted large losses, but also the most highly reputable of funds, such as Goldman Sachs flagship Global Alpha fund have posted double digit drops. ${ }^{63}$

Investors who successfully withdraw money from a struggling hedge fund may still be at risk. If a hedge fund fails, in some cases, a bankruptcy trustee or other investors may sue investors who have already redeemed money and try to force them to pay that money back into the fund. ${ }^{64}$ The trustee could argue that, the hedge fund did not value its assets correctly and that investors withdrew more money than they were entitled to, the lawyers

\footnotetext{
${ }^{56}$ Andrew Ross Sorkin, Redemption Day: Will Hedge Fund Investors Bolt? NEW YORK TIMES. Available at http://dealbook.blogs.nytimes.com/2007/08/15/redemption-day-will-hedge-fundinvestors-bolt/ (last visited October 17, 2007).

${ }^{57}$ Supra note 37.

${ }^{58}$ See id.

${ }^{59} \mathrm{Id}$.

${ }^{60} I d$.

${ }^{61}$ See Sorkin, supra note 43.

${ }^{62}$ Grace Wong, Hedge Fund Redemption Shock: Investors Looking to Cash Out This Fall May be Met With Unpleasant Surprise, CNNMONEY, Aug. 27, 2007. Available at

http://money.cnn.com/2007/08/23/markets/hedge_fund_redemptions/index.htm?section=money_topst ories (last visited October 20, 2007).

${ }^{63}$ See Opdyke, supra note 37.

${ }^{64} I d$.
} 
say. ${ }^{65}$ This concept may well apply to some of the fund failures right now, because some funds involved with, say, subprime-mortgage-related securities may have a hard time valuing their assets and could wind up in bankruptcy. "It's the Hotel California syndrome, you can check out anytime you like, but you can never leave." "66 Investors need to read hedge fund offering documents and limited-partnership agreements carefully to understand redemption rules. ${ }^{67}$ Individual investors rarely read this language, and given the success of hedge funds in recent years, the efforts of the wealthy have all been focused on finding ways to get their money in to these funds, which tantalize with the potential for enormous return.

In some cases, funds may impose a penalty on investors who try to withdraw money without giving proper notice or require longer redemption notice periods for investors who want to take out money at year end. ${ }^{68}$ In some cases, investors have negotiated in advance special agreements with hedge fund managers known as a "side letter", which may allow the investor to redeem money more quickly than other investors in the fund. ${ }^{69}$ The viability of securing this type of agreement with the fund manager is not likely to be equally shared by all hedge fund investors, even though individual investments in these funds are substantial. Often, such agreements are reserved for very large institutional investors such as endowments and pension funds. $^{70}$

Some funds will on occasion waive the redemption period, allowing anxious investors to exit early, but this sort of policy is very dependent on the given fund, as many funds are run very differently than others. ${ }^{71}$ Specifically, funds controlled by large investment banks will generally conduct themselves differently than individual funds that have no reputation outside the specific fund to be accountable to. ${ }^{72}$ As is evident from the turmoil resulting from the collapse of two large Bear funds, fund insolvency reflects extremely poorly on the credibility of an institution as a whole, something the large investment banks are well aware of in the current market. Regardless of fund management and these factors that may affect operation style, investors should be advised to be very active and vocal in their involvement with the fund manager. If an investor is thinking of

\footnotetext{
${ }^{65} \mathrm{Id}$.

${ }^{66}$ See Wong, supra note 52.

${ }^{67}$ See Opdyke, supra note 37.

${ }^{68} \mathrm{Id}$.

${ }^{69}$ See Wong, supra note 52.

${ }^{70} \mathrm{Id}$.

${ }^{71} \mathrm{Id}$.

${ }^{72}$ See Opdyke, supra note 37.
} 
putting money into a fund, especially given the large amounts in question, they should be very persistent on securing contractual language that allows for clear and investor-friendly redemption, if at all possible.

\section{REDEMPTION RELATED ISSUES AND FRAUdULENT CONVEYANCE STATUTES}

As hedge funds are susceptible to collapse given their extreme leveraged positions, investors must be very aware of what fund managers are doing with money if matters go south. Issues of fraudulent conveyances have raised their head in these situations, and although these would appear likely to be the rogue funds without huge assets, no fund is immune from this line of questioning. Specific questions of law that must be examined are: how the fraudulent conveyance statute relates to redemption requests, and determining what is the definition of insolvency under the fraudulent conveyance statute.

The basic definition of insolvent, to the lay individual, means the inability to pay debts. Under traditional legal definition ${ }^{73}$, a corporation is solvent if, and only if, it is able to pay all its debts, as and when they become due and payable (s95A of the Corporations Act). The Bankruptcy Act, however, refers to the debtor's ability to pay debts "from his or her own money" (s122(4)(c)), as did older versions of corporate insolvency legislation. ${ }^{74}$ A recent decision suggests a corporation will not be required to be able to pay debts from its own moneys to demonstrate solvency. ${ }^{75}$

In bankruptcy proceedings, a trustee is chosen to administer the debtor's estate in a fair and orderly manner. ${ }^{76}$ Generally speaking, for bankruptcy purposes, the estate is comprised of those assets of the debtors in which the debtor's creditors have an interest. ${ }^{77}$ The trustee is given the power to set aside or "avoid" certain transfers of the debtor's assets out of the estate that unfairly place assets beyond the creditor's reach. ${ }^{78}$ Such a transfer of the debtor's assets to a third party, with the intent to prevent creditors from reaching the assets to satisfy their claims, is called a

\footnotetext{
${ }^{73}$ Refers to American Legal Conception of Insolvency as provided by the CORPORATIONS ACT.

${ }^{74}$ See THE BANKRUPTCY ACT (122(4)(c)).

${ }^{75}$ Under the Bankruptcy Code, insolvency exists when the sum of the debtor's debts exceeds the fair value of the debtor's property, with some exceptions. It is a balance sheet test. 11 USC § 101(32). ${ }^{76} \mathrm{Id}$.

${ }^{77} 11$ USC $\S 544$ (b) allows trustees to employ applicable state law to recover fraudulent transfers. The time period under the UFTA is in most cases four years before action is brought to recover-UFTA $\S$ 9.

${ }^{78}$ This is done through the mechanism of avoidance of the transfer. 11 USC $\S 548$.
} 
"fraudulent conveyance". ${ }^{79}$ This is also referred to commonly as a "fraudulent transfer", and for the purposes of this legal issue, the terms can be considered synonymous. ${ }^{80}$

There are two types of fraudulent transfers in bankruptcy law. The first, actual fraud, involves the intent to defraud creditors, the other, sometimes called constructive fraud, involves a transfer, which is made in exchange for grossly inadequate consideration. ${ }^{81}$ Actual fraud is committed when a transfer is made within one year before the date of the filing of a bankruptcy petition, and is made with the intent to hinder or defraud a creditor. ${ }^{82}$ Actual fraud requires proof of intent from the person challenging the transfer. Of course, a debtor intending to defraud his creditors will not be overt about his intentions to do so. ${ }^{83}$

Therefore, courts have set forth circumstances which indicate the intent to defraud. ${ }^{84}$ Some examples of these circumstances are actual or threatened litigation against the debtor, retention of possession or control of the property, transfer of substantially all the debtor's assets, transfer to a newly created corporation, and a special relationship with the person to whom the property is transferred. ${ }^{85}$ These are only factors to be considered in determining whether a person intended to defraud a creditor, and whether they do in fact prove the debtor's fraudulent intent is to be determined on a case by case basis. ${ }^{86}$

One of the most important badges of fraud for purposes of assessing a fraudulent conveyance is the debtor's insolvency, or solvency, before and after the conveyance in question. Most state statutes and other laws do not clearly define solvency or show how to measure solvency. ${ }^{87}$ The principle issue is whether assessment of solvency includes in the debtor's assets those assets that are exempt from creditors such as homestead property, annuities and retirement funds. Computation of solvency under Bankruptcy law

\footnotetext{
${ }^{79} 11$ USC $\S 548(2)$; UFTA $\S 4(a)(2)$.

${ }^{80}$ The Uniform Fraudulent Transfer Act, which is available in PDF format at: http://www.stcl.edu/rosin/ufta84.pdf (last visited October 18, 2007). As of June, 2005, 43 states and the District of Columbia had adopted it. The UFTA is preceded by the Uniform Fraudulent Conveyance Act, which initially sought to codify and standardize law in the area for the ease of commercial law across the state.

${ }^{81}$ See id.

${ }^{82} 11$ USC $\S 548(2) ;$ UFTA $\S 4(a)(2)$.

${ }^{83}$ See, e.g., Nisenzon v. Sadowski, 689 A.2d 1037 (R.I. 1997); Cellar v. Holley, 9 Ohio App. 2 d 288 (1967); Larrimer v. Feeney, 411 Pa. 604 (1963).

${ }^{84} \mathrm{Id}$.

${ }^{85} \mathrm{Id}$.

${ }^{86}$ See Moody v. Security Pacific Business Credit, Inc., 971 F.2d 1056, 1064 (3d Cir.1992).

${ }^{87}$ Id.
} 
excludes exempt assets; the tax code definition includes exempt assets. ${ }^{88}$ For example, Florida Statute $726.103^{89}$ states that, "a debtor is insolvent if the some of the debtor's debts is greater than all of the debtor's assets" or secondly, the debtor is generally not paying his debts when due. ${ }^{90}$ The first part of the Statute's definition does not specify whether exempt assets are considered, and therefore, the second test of debt payment becomes most important. $^{91}$

Under the UFTA and Bankruptcy Code, different bases of valuation may be appropriate depending upon the circumstances, and different methods of determining value on any particular basis may be appropriate depending upon the business engaged in by the debtor and other factors. ${ }^{92}$. For a debtor which is a business enterprise, valuation on the basis of continuation of the business by the debtor as a going concern ordinarily would be the appropriate basis of valuation if, at the time as of which the valuation is made, it reasonably would be expected that, the enterprise will continue as a going concern. ${ }^{93}$ In such a case, appropriate values may be ascribed to goodwill and to non-assignable licenses, franchises, contracts and rights. ${ }^{94}$. Often it would be appropriate not to attempt to determine the value of separate assets and debts, but rather to determine only the "enterprise value" representing the aggregate difference between the debtor's assets and debts. ${ }^{95}$

Enterprise value should be determined by methods appropriate under the circumstances which can include the capitalization or discounted cash flow methodology. ${ }^{96}$ Even if it is appropriate to value on a liquidation basis, this may mean carving up the company into smaller going concern units rather than a piecemeal forced liquidation. ${ }^{97}$ In any event, the GAAP balance sheet, while a starting point for the analysis, is not dispositive of value. $^{98}$

\footnotetext{
${ }^{88}$ See Vadnais Lumber Supply, Inc. v. Byrne (In re Vadnais Lumber Supply, Inc.), 100 B.R. 127, 131-32 (Bankr. D. Mass. 1989).

${ }^{89}$ Florida code is used here as it reflects a great deal of code provisions of this regard, though it is not meant to serve as the definitive source of code.

${ }^{90}$ See supra note 88 .

${ }^{91} \mathrm{Id}$.

${ }^{92}$ See Committee Comment $1(1993) \S 5102$.

${ }^{93} \mathrm{Id}$.

${ }^{94} \mathrm{Id}$.

${ }^{95} \mathrm{Id}$.

${ }^{96} \mathrm{Id}$.

${ }^{97} \mathrm{Id}$.

${ }^{98}$ See Vadnais Lumber Supply, Inc. v. Byrne (In re Vadnais Lumber Supply, Inc.), 100 B.R. 127, 131-32 (Bankr. D. Mass. 1989), discussing the proper standard of valuation to be applied in the determination of solvency under the Bankruptcy Code, appears to be an example of what is intended by the UFTA.
} 
As set forth in Vadnais Lumber, the proper standard of valuation is the value of the business as a going concern, not the liquidation value of its assets less its liabilities, provided that, the business was a going concern at the time of the transfer. On the other hand, liquidation value is appropriate if, at the time of the transfer, the business is so close to shutting its doors that a going concern standard is unrealistic. In Vadnais Lumber, the court found that, although the business was weak after the transfer, the debtor was still able to continue its business operations without a bankruptcy for some period of time. ${ }^{99}$

A reasonable construction of UFCA $\S 4$ indicates that, it not only encompasses insolvency in the bankruptcy sense, but also includes a condition wherein a debtor has insufficient presently salable assets to pay existing debts as they mature. ${ }^{100}$ If a debtor has a deficit net worth, then the present salable value of his assets must be less than the amount required to pay the liability on his debts as they mature. A debtor may have substantial paper net worth including assets which have a small salable value, but which if held to a subsequent date could have a much higher salable value. ${ }^{101}$ Nevertheless, if the present salable value of assets is less than the amount required to pay existing debts as they mature the debtor is insolvent.

\section{BAYOU BANKRUPTCY SCENARIO}

Risks to hedge fund investors may now linger even after they have redeemed their interests in the funds. Such a notion of risk long after exit seems unlikely, but if the receiver, acting as Chapter 11 manager of the defunct Bayou hedge funds, ultimately prevails in actions to recover $\$ 140$ million from investors who withdrew from the funds within two years of bankruptcy filings. ${ }^{103}$ According to a February 23, 2007 decision by a

\footnotetext{
${ }^{99}$ See also, Moody v. Security Pacific Business Credit, Inc., 971 F. 2d 1056, 1076-69 (3d Cir. 1992); In re Taxman Clothing Co., 905 F. 2d 166, 169-70 (7th Cir. 1990) (under Bankruptcy Code avoidance action going concern value is proper method for determining solvency unless business is on its deathbed).

${ }^{100} I d$.

${ }^{101}$ Though inability to meet obligations does not conclusively establish insolvency under the UFCA, courts have found this to be a reliable indication of insolvency where there is little direct evidence of a debtor's assets and liabilities. See, e.g., Nisenzon v. Sadowski, 689 A. 2 d 1037 (R.I. 1997); Cellar v. Holley, 9 Ohio App. 2d 288 (1967); Larrimer v. Feeney, 411 Pa. 604 (1963).

${ }_{102}$ Peter Lattman, Bankrupt Bayou Wants Its Money Back, WALL StreEt Journal, May 30, 2007, at B1. See also compilation of court documents related to the Bayou liquidation. Available at http://www.bayoucaymanliquidation.ky/committee.htm (last visited October 17, 2007).

${ }^{103}$ Diya Gullapalli, Fund Track: Buyout Boom Helps Some Investors, WALL ST. J., Feb. 23, 2007, at C1.
} 
bankruptcy judge in the U.S. Bankruptcy Court in the Southern District of New York, denying the motions to dismiss in 95 separate lawsuits against the redeeming investors, the complaints stated enough to make a prima facie case to recover both principal and "profits" as fraudulent conveyances under federal and state law. ${ }^{104}$

What the plaintiffs know about the operations of the Bayou hedge funds over their nine-year history is derived largely from the criminal complaints against the principal organizers Samuel Israel III and Daniel Marino and their guilty pleas. ${ }^{105}$ Israel and Marino, who are currently awaiting sentencing, admitted to lying to investors in the Bayou hedge funds by sending the investors regular reports that contained fictitious rates of return on trading and inflated net asset values in order to conceal losses. ${ }^{106}$

The facts in the criminal actions, largely parroted in the complaints against the redeeming investors, were accepted as true by the court in denying the dismissal motions. ${ }^{107}$ However, whether the profits each investor received were "fictitious" and the hedge funds were insolvent or rendered insolvent at the time, each of the redeeming investors were paid must still be developed by the plaintiffs from a reconstruction of books and records and proven at trial. ${ }^{108}$ It is estimated that, the non-redeeming investors of four domestic funds and one offshore fund are owed $\$ 250$ million before distributions from a victims' fund set up by the U.S. Department of Justice to compensate these investors for their losses. ${ }^{109}$ There is currently more than $\$ 106$ million in the victims' fund from assets seized and collected by various state and federal agencies. ${ }^{110}$

The plaintiffs hope to make up some of the shortfall for the nonredeeming investors from those who redeemed in whole or in part before the collapse, notwithstanding the fact that, none of the redeeming investors are accused of having participated in the fraud. Those efforts have been vigorously opposed by the defendants who sought dismissal of the lawsuits collectively based on a decision in the Second Circuit Court of Appeals that insulates payments from recovery on an intentional fraudulent conveyance theory when such payments are made to satisfy an antecedent debt. ${ }^{111}$

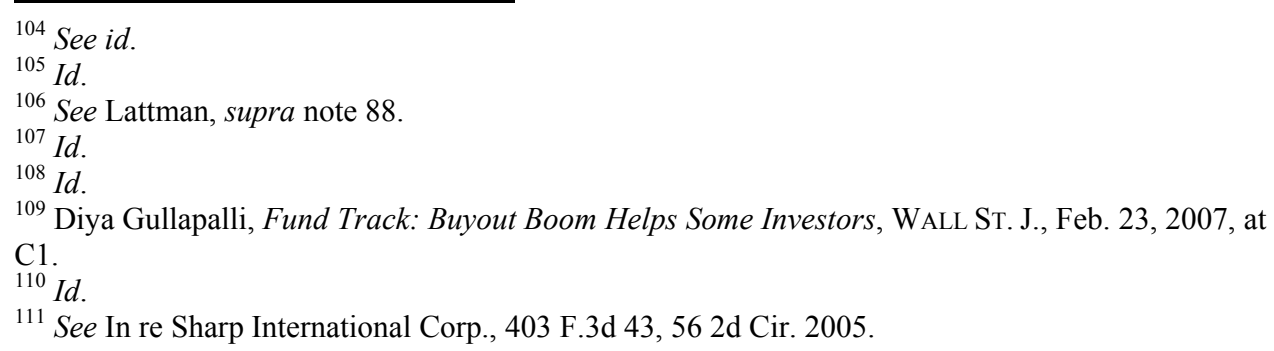


The defendants argued that, they fit within the Sharp protections because they had existing claims for rescission or restitution against the hedge funds based on the fraudulent inducement to invest that were satisfied with the redemption payments. ${ }^{112}$ The defendants also attempted to rebut the contention that, the hedge funds were operated as a massive Ponzi scheme on the grounds that operations had none of the characteristics of a classic Ponzi scheme: there were no promises of unrealistic or high returns, Bayou had substantial business operations, and the redeeming investors were not paid out by late investors in the hedge funds. ${ }^{113}$

The ramifications of this decision are clearly not positive for the investor community. It leaves investors with significant uncertainty even after they have redeemed their investment from a fund as they continue to be exposed to risk of loss, if only the cost of litigation, should a situation such as Bayou arise. ${ }^{114}$ The possibility of such occurrences is certainly a negative in the eyes of large investors, particularly scrutinized institutional investors. Furthermore, the general negative light under which hedge funds are portrayed is exacerbated by such activity, meaning that, the actions in liquidation by other funds will be highly scrutinized, and transfers will have to clearly pass the test to not qualify as fraudulent, or face likely court intervention.

The U.S. Bankruptcy Court for the Southern District of New York denied a motion to dismiss made by investors who had redeemed their interests in three Bayou hedge funds in the two years prior to the bankruptcy filing. ${ }^{115}$ The bankruptcy trustee sought to clawback payments made to these investors pursuant to the "fraudulent conveyance" provision in the Bankruptcy Code that permits clawback of payments made by a debtor with intent to defraud other creditors. ${ }^{116}$ The three Bayou hedge funds are alleged to have significantly inflated their net asset values and to have utilized a fictitious accounting firm to "audit" their returns starting in 1999, before the fraud was uncovered and the Bayou funds collapsed in 2005 . $^{117}$

During 2003-2005, investors who redeemed their interests in the Bayou funds received redemption proceeds based on the false inflated NAVs

\footnotetext{
${ }^{112}$ Peter Lattman, Bankrupt Bayou Wants Its Money Back, WALL Street Journal, May 30, 2007, at B1.

${ }^{113} I d$.

${ }^{114}$ Diya Gullapalli, Fund Track: Buyout Boom Helps Some Investors, WALL St. J., Feb. 23, 2007, at C1.

${ }^{115}$ See id.

${ }^{116} \mathrm{Id}$.

${ }^{117} \mathrm{Id}$.
} 
reported by the Bayou funds. ${ }^{118}$ The court ruled that, the redemption payments are subject to clawback under the fraudulent conveyance statute and thus denied the investors' motion to dismiss. ${ }^{119}$ It further ruled, however, that the redemption payments received by the investors may be subject to a good faith defense but that more evidence is needed to determine whether the good faith defense is available to these investors. ${ }^{120}$

\section{CONCLUSION}

Dealings in extreme leverage mean that, there will be volatility. With risk spread throughout the market by quants and funds of funds, exacerbated by the copycat nature of the hedge fund business, many legal implications come to the foreground in terms of getting money out of these funds, and exposure to risk in cases of fund bankruptcy. Hedge funds will likely to continue to grow in power. Some funds will fail, but such is the nature of capital markets, compounded by leveraged positions.

This does not mean that, hedge funds will all be in trouble; on the contrary, hedge funds will continue to play an increasingly important part in the global economy. Hedge funds, along with private equity, oil money from the Middle East and Asian Central banks, have been noted to be the big players for the future of the global economy. ${ }^{121}$ The more hedge funds there are, the more they become integral to our capital market system, and the higher percentage of daily trade volume they will occupy. This also means that, by sheer numbers, more funds will invariable collapse. The legal system must be prepared to deal with these collapses. Also, the economy and its investors need to realize that collapse of funds is bound to happen, but that these will not mean that, many funds will not continue to yield amazing return.

Fund collapse will not be a regular phenomenon, but will happen on occasion, likely as a result of market conditions that expose the risk of dealing with positions of extreme leverage. Investors in these funds should be very aware of the partnership agreement provision or corporate organizational provision that governs the withdrawal of funds. Those who have money in hedge funds should be cognizant of the fact that, unlike mutual funds, hedge funds do not have mandatory seven day withdrawal

\footnotetext{
${ }^{118}$ Peter Lattman, Bankrupt Bayou Wants Its Money Back, WALL STReEt Journal, May 30, 2007, at B1.

${ }^{119} I d$.

${ }^{120} I d$.

${ }^{121}$ Wall Street Journal article on Future of Powerful Financial Institutions. Available at http://online.wsj.com/article/SB115862648061466997.html (last visited October 6, 2007).
} 
provisions, and because of the secretive nature of hedge funds, it is often hard to get answers on exact policy. Because fund collapse has not been in the forefront of concern in recent years of great leveraged success, it is important that, legal issues be examined for future reference, especially given the massive amounts of capital being pooled into hedge funds.

Fraudulent transfers come into the forefront of legal concern in the case of insolvency of funds, or even in liquidation attempts prior to complete insolvency. Because hedge funds manage such vast amounts of capital and can often be in positions of sizable risk, quick actions and dispersal of funds, coupled with redemption requests in quick succession, can lead to problems mirroring the proverbial run on the bank.

The Bayou collapse brings together all of the legal issues related to redemption requests, fund insolvency, fraudulent transfers and the ugly prospect of transfer liability. ${ }^{122}$ During 2003-2005, investors who redeemed their interests in the Bayou funds received redemption proceeds based on the false inflated NAVs reported by the Bayou funds. ${ }^{123}$ The court ruled that, the redemption payments are subject to clawback under the fraudulent conveyance statute and thus denied the investors' motion to dismiss. ${ }^{124}$ It further ruled, however, that the redemption payments received by the investors may be subject to a good faith defense but that more evidence is needed to determine whether the good faith defense is available to these investors. ${ }^{125}$ This evidence will be expensive and time-consuming to collect, and is the type of work that generates high legal fees and is going to frustrate those with money in funds, regardless of ultimate outcome. ${ }^{126}$

The events of Bayou, as well as the Bankruptcy Court treatment of the Bear Stearns funds to this point, provide a template by which to analyze the possibilities for future developments in the area. ${ }^{127}$ Important to recognize is that, Bayou represents the legal ramifications for what is possible if the fund managers are willing to engage in fraudulent conduct. This will not always be the case in the event of collapse. With Bear Stearns' collapse, this type of behavior is less likely to occur. However, the ramifications of Bayou demonstrate that, this type of conduct is possible, and given that large, respected funds are susceptible to collapse, the complete range of legal consequences must be considered in order to fully advise investors what they could possibly be forced to deal with.

\footnotetext{
${ }^{122}$ Supra note 98.

${ }^{123} \mathrm{Id}$.

${ }^{124} \mathrm{Id}$.

${ }^{125}$ Supra note 105.

${ }^{126} \mathrm{Id}$.

${ }^{127} \mathrm{Id}$.
} 
Fraudulent transfer situations present nightmare for the elite, asset rich investors who generally engage in hedge fund speculation, likely giving rise to liability that they never thought possible when putting their money into a hedge fund. Even if no fraudulent transfers occur, it is imperative that, investors recognize their rights with respect to redemption, be that if they simply want to redeem funds for fear of downswing, or in cases of insolvency. 